\title{
Agri Tourism as a Risk Management Strategy in Rural Agriculture Sector: With Special Reference to Developing Countries
}

\author{
Rohana P Mahaliyanaarachchi ${ }^{1}$ \\ Received : 16 $6^{\text {th }}$ September 2015 / Accepted : 23 $3^{\text {rd }}$ September 2015
}

\begin{abstract}
This article reviewed literature on potential of agri tourism as a risk management strategy in rural agriculture sector with special reference to developing countries. Reviewing literature indicated that agri tourism as a risk management strategy in rural agriculture sector has an immense potential to contribute to manage the risk in agricultural economy. Evidence from the production and price fluctuations during last three to four decades in both conventional agriculture sector with intensive production of rice, vegetables, and other subsistence crops and plantation agriculture sector with intensive production of tea, rubber, coconut, coffee, etc shows that they are highly vulnerable to external factors such as internal \& international politics, climate change and whether pattern changers, market and trade slumps, etc. Sudden and unanticipated influences of these external factors cause higher risks in sustainability of agriculture sector and it results in the collapse of both micro and macro economies in a country. This paper attempts to discuss how agri tourism can be introduced to agriculture sector as a supplementary income source as a risk management strategy which is less susceptible to above mentioned externalities. Further, agri tourism will motivate and encourage farming communities to raise their crops in eco friendly approach and to conserve the biodiversity of farms which will minimize the internal risk factors of farming such as pest and disease outbreaks, soil degradation, etc. Research studies has shown that a well-developed agri tourism industry would result in a market mechanism generating additional income of US \$251 to US \$364 million annually in counties like Dominican Republic. Agri tourism sector would improve sustainable agricultural practices by maintaining and increasing positive externalities and nonmarket services provided by agriculture. Agri tourism products and services would have the added benefit of promoting sustainable agricultural practices too. This is a good option for farmers and planters who are willing to diversify their farming operations that will help bringing more economic activities to rural areas sustaining livelihoods of the rural people. In addition, agri tourism not only allows farmers to enjoy greater economic benefits through managing risks, but also helps to retain the young generation of the farming community in the rural areas instead of migrating to urban areas for better livelihoods.
\end{abstract}

Keywords: Agri tourism, risk, management, rural agriculture, economic development

\section{INTRODUCTION}

This article reviewed literature on potential of agri tourism as a risk management strategy in rural agriculture sector with special reference to developing countries. It is also provided a review of agri tourism development particularly in emerging economies in Asia, Africa and Latin America. Reviewing literature indicated that agri tourism as a risk management strategy 
in rural agriculture sector has an immense potential to contribute to manage the risk in agricultural economy.

Evidence from the production and price fluctuations during last three to four decades in both conventional agriculture sector with intensive production of rice, vegetables, and other subsistence crops and plantation agriculture sector with intensive production of tea, rubber, coconut, coffee, etc shows that they are highly vulnerable to external factors such as internal \& international politics, climate change and whether pattern changers, market and trade crumples, etc. Sudden and unanticipated influences of these external factors cause higher risks in sustainability of agriculture sector as a consequence both micro and macro economies in a country collapses.

\section{Types of risks faced by farming sector}

Farming activities are subject to wide range of risks due to biological, physical and economic environment in which farming operates. Most of these risks are specific to agriculture and they affect to the overall production and economic efficiency of agricultural production system. Further, these risks cause to fall of farm incomes, welfare of agricultural workers with potential to constraint future investment and growth of farm production. Therefore, it is important to understand how the presence of risks in agricultural production affects the economy and how these risks can be mitigated.

The main risks in farming can be categorized as follows (OECD, 2008).

a. Production or yield risk : this is uncertainty about the volume or quantity of agricultural production due to weather related factors such as heavy rains, floods, droughts, cyclones and typhoons, tornadoes, frosts, heavy snow falls, hails, etc , crops and livestock diseases, pest outbreaks and change of technology. b. Market or price risk: uncertainty and fluctuations of prices of both inputs and outputs (agricultural production) due to market instabilities, trade policies of the governments, new markets, etc

c. Regulatory risk: unexpected changers of national agricultural policies, environmental regulations, provincial government laws, and trade policies. This may happen due to change of rulers or any other political reasons

d. Financial and management risk: changers of bank policies and its credit facilities, change of interest rates, fluctuations in the share market, international and national financial crisis, management change

e. Personal risk: personal hazards such as illness, death, theft, injuries, family crisis, etc

There are various other classifications for agricultural risks faced by farmers other than above given classification. Nevertheless, all the deferent types of risks given in the literature can be grouped into above given five categories and is shown in table 1 .

According to OECD (2011) there are three different layers of agricultural risks and they require different mitigation strategies.

- Normal risks: They do not need any specific policy response from government or relevant authorities. They can directly managed by farmers as a normal business strategy

- Catastrophic risks: Many or all farmers in a region or country get affected by these risk sources and usually are beyond farmers or markets capacity to cope. Examples for this type of risk sources are severe, prolonging and widespread droughts, outbreak and spread of a highly contagious and damaging diseases or pests and unexpected, severe floods. In such cases government invention is unavoidable. 
- Marketable risks: In between normal and catastrophic risk layers lies marketable risk layer that can be handled through market tools. These tools are crop insurance, extended markets, cooperative systems, guaranteed prices, etc.

Further, there is a difference between systematic and non systematic risks. Systematic risks repeat over time with a pattern of probabilities that can be analysed in order to have a good estimate of the actuarial probability. Non-systematic risks are very short or imperfect records of their occurrence and, therefore, difficulties in estimating an objective pattern of probabilities or distribution of outcome (Newbery and Stieglitz, 1981). If there is a high degree of correlation among individuals in the same region or country the risk is called systemic risk. An individual risk that is independent and uncorrelated with any other risks is called idiosyncratic risk. However, it is important to have an idea about degree of correlation among these different types of risk in finding solutions to mitigate them (Jorion, 2001).

\section{Factors influencing risks in farming sector}

The overall impact of risks both on individual farms and on whole farming sector in a region depends on the relationships between the different risk factors. In the broader sense, correlation between risk factors can differ significantly that affects the overall risk exposure of farm enterprises. When risks are not perfectly correlated at farm level, total risk exposure will be less than the sum of individual risks (OECD, 2009). Therefore it is important to consider that relationships between risk factors allows the possible effects on farm income to be determined more accurately and introduce risk management strategies more effectively.

Table 01: Major risks faced by farmers

\begin{tabular}{|c|c|c|c|}
\hline Risk Group & Type of risk & Examples & Effects \\
\hline \multirow{3}{*}{$\begin{array}{l}\text { Production or } \\
\text { yield risks }\end{array}$} & Weather & $\begin{array}{l}\text { Deficit or excess rainfall, extraordinary } \\
\text { temperatures (both high and low), strong winds, } \\
\text { hail storms }\end{array}$ & Loss of crops, lower yields, income loss \\
\hline & Natural disaster & $\begin{array}{l}\text { Floods, prolonging droughts, cyclones, typhoons, } \\
\text { volcanic activities, earth slips, earthquakes, } \\
\text { tornados }\end{array}$ & $\begin{array}{l}\text { Damage of crops and loss of animals, } \\
\text { complete or partially loss of yields, } \\
\text { infrastructure losses, totally or partially } \\
\text { damage and loss of farms }\end{array}$ \\
\hline & Biological & $\begin{array}{l}\text { Diseases and pest outbreaks ( for both crops and } \\
\text { livestock), contamination of micro organisms, } \\
\text { heavy metals or chemicals }\end{array}$ & $\begin{array}{l}\text { Damage of crops and loss of animals, } \\
\text { complete or partially loss of yields, loss } \\
\text { of income }\end{array}$ \\
\hline \multirow[t]{2}{*}{ Market or price } & Market & $\begin{array}{l}\text { Unexpected changes of demand for certain } \\
\text { products, changers of food safety requirements, } \\
\text { delaying of delivery, damages during transport, } \\
\text { changers of supply chain stakeholders }\end{array}$ & $\begin{array}{l}\text { Loss of markets, lower prices, loss of } \\
\text { production, loss of income, }\end{array}$ \\
\hline & Price & Low prices, volatility of prices & Loss of income \\
\hline \multirow{2}{*}{ Regulatory risk } & $\begin{array}{l}\text { Policy and } \\
\text { Institutions }\end{array}$ & $\begin{array}{l}\text { Regulatory changers, uncertain legal policies, } \\
\text { weak institutional capacities, unfavorable tax } \\
\text { policies, }\end{array}$ & Fluctuations of prices, low income \\
\hline & Politics & $\begin{array}{l}\text { Government related uncertainty, political } \\
\text { upheaval, social unrest, wars, employees strikes } \\
\text { of supply chain }\end{array}$ & Fluctuations of prices, low income \\
\hline \multirow{2}{*}{$\begin{array}{l}\text { Financial and } \\
\text { management } \\
\text { risk }\end{array}$} & $\begin{array}{l}\text { Logistics and } \\
\text { infrastructure }\end{array}$ & $\begin{array}{l}\text { Change cost of transportation, energy and } \\
\text { communication, low quality transport facilities, } \\
\text { energy and information }\end{array}$ & High COP, low profits or losses \\
\hline & $\begin{array}{l}\text { Management and } \\
\text { operations }\end{array}$ & $\begin{array}{l}\text { Poor management decisions, poor quality control, } \\
\text { poor forecasting of demand and supply, }\end{array}$ & Fluctuations of prices, low income \\
\hline Personal risk & $\begin{array}{l}\text { Labour and } \\
\text { health }\end{array}$ & $\begin{array}{l}\text { Illness, death, injury, theft, family crisis, labour } \\
\text { scarcity }\end{array}$ & $\begin{array}{l}\text { Loss of productivity, high COP, loss of } \\
\text { income }\end{array}$ \\
\hline
\end{tabular}

Source: Jaffee S. et al , 2010, and Author 
However, in practice calculating the effect and strength of the risks and interaction effect of different risk factors may be highly complex.

It is important to consider how risk factors affect different farmers. Systematic risks such as droughts, floods and price fluctuations which are specific to a particular region or country are highly correlated within the group of farmers. In other hand distinctive risks such as localized weather conditions (hail, frost, etc) and personal risks (death, illness, theft, etc) are unrelated to the farming community as a whole. They are affected only to individual cases.

Risks in agriculture are interconnected and sometimes merging or sometimes counteracting each other. As an example when production is declined due to risk factors related to production, these risks can be partially offset by price movements, if the prices of products are relatively high (OECD, 2011).

There are two major types of agricultural risk and factors influencing these risks are different to each other (Huirne et al, 2000; Hardaker et $a l, 2004)$. First category is business risk and it includes production, market, institutional and personal risks. Factors affecting production risk aremainlyunpredictableweatherandunexpected outbreaks of pests \& diseases. They directly affect performance of crops and livestock. Market risk is related to uncertainty about the price of outputs and, sometimes also inputs, at the time production decisions are taken. Factors affecting market risk are sudden changers of markets, unusual changers of consumer behaviour, high fluctuations of supply and demand and unexpected crisis on food safety in the supply chain. Factors affecting institutional risk are government actions and rules on food production and distribution, regulations on use of agro chemicals, tax provisions and payments. Factors affecting personal risks are uncertain life events such as death, divorce, theft or illness. Second category is financial risks resulting from different methods of financing the farm business. The use of borrowed funds means that interest charges have to be met before equity is rewarded which may create risk due to leverage. Therefore, factors affected on financial risk are interest rates rise or unavailable of bank loan for agriculture.

\section{External}

External factors affecting risk of farming (both crop production and livestock) are mainly influenced to the farming process from outside of the farm. These factors are less controllable by the farmer. Nevertheless, farmer as an individual or farming community can take measures to mitigate the effect of these factors. Unpredictable weather is an external factor that cannot be controlled by the farmers. Deficit or excess rainfall, extraordinary temperatures (both high and low), strong winds, hail storms, tornados and such unfavorable weather conditions to farming cause for adverse effects on farm production and subsequently for total farm income and profitability. Other external factors affecting risk of farming are sudden changers of markets, unusual changers of consumer behaviour, high fluctuations of supply and demand and unexpected crisis on food safety in the supply chain, government actions and rules on food production and distribution, regulations on use of agro chemicals, tax provisions and payments, interest rates rise and unavailable of bank loan for agriculture.

\section{Internal}

Internal factors affecting risk of farming mainly influences the farming process from inside of the farm. Some of these factors are controllable by the farmers and some are not. Unexpected outbreaks of pest and diseases are mainly within the farming region. Reasons for pest and diseases outbreaks are different and some of them are controllable by the farmers some are not. Some of these reasons are deforestation, destruction of natural enemies, intensive cultivation, introduction to new varieties and crops, modern agricultural practices and 
accidental introduction of pests and diseases from foreign countries. Unexpected climatic conditions also cause for some pest and diseases outbreaks. Farmers incur large economic losses due to attacks from pests and diseases. Therefore, this is a major risk faced by farmers and it is needed measures to control them and mitigate the effects.

Uncertain life events such as death, divorce, theft or illness are also internal risk factors in farming.

\section{Risk management strategies}

Risk management should not concentrate on only one risk factor or only one solution. Diversification is a good strategy to reduce agricultural risk. Within the normal risk layer individual farmers are responsible and capable for managing their own business risk. Farmers adopt various strategies to manage risk affecting their production and income. These strategies depend on the characteristics of risk they face, their attitude to risk and the risk management instruments and tools available (OECD, 2009a).

There are four main types of risk management strategies available in the literature.

They are financial strategies, marketing strategies, production strategies and insurance. Other than the financial and marketing strategies, production strategies such as diversification, geographic dispersion, variety selection, timeliness, the use of cultural practices best suited to particular areas, etc. are important ways to manage risk. Diversification has been one of the more important and useful method to reduce risk and uncertainty. The chance of a large economic loss from a given hazard is reduced if there is more than one enterprise in the farm business. However, enterprises included in the business should not be subject to the same hazards or at least not to the same degree, if this strategy to be more effective in risk management (OECD, 2009b).

\section{Agri tourism as a risk managing strategy}

Agri tourism is an enterprise that can be introduced to diversify farm business successfully. While agri tourism is a mix of two major sectors- agriculture and tourism, agri tourism farms are not subject to the same hazards faced by agriculture only farms.

\section{What is agri tourism?}

Agri tourism is the practice of attracting visitors to an area used basically for agricultural purposes. It attracts tourists to rural communities for a form of relaxation that follows the growing trend of tourism that is both educational and recreational. Also it is another option for farmers wanting to diversify their farming operations that will bring more economic activities to rural areas. Generally, the image of tourism stimulates of mass-produced travel that attracts a large number of travelers. This image of mass tourism may discourage small entrepreneurs who consider tourism as an alternative option for enhancing their revenues. However, agri tourism can be viewed as small-scale, lowimpact, education focused, recreational and more importantly compensating income for agri tourism operators that are mainly farmers.

Further, Agri tourism is a direct marketing activity which provides additional opportunities to farmers to reduce risks involved in farming via diversification in a competing and urbanizing economic environment. While farmers get separate income from agri tourism products that they sell to the visitors, they are more riskless than expecting income from one operation that is merely farming.

It can provide many benefits to the farmers:

- Supplementary income for the farmer apart from farming

- Continuous cash flow all around the year including the off-season 
- Opportunity to sell products grown and harvested in the farmer's agricultural operation

- Opportunity to sell the "experience" of farmers agricultural venue

- Managing the risk in farming occurred due to uncertainties of production and marketing

\section{Products of agri tourism}

\section{Classification of Agri tourism products and services}

Agri tourism products are spreading in a wider range. Agri tourism products are not merely activities. It is included place of implementing the activities, people involved, facilities needed for tourists, something to see, something to do (activities) and something to buy the visitors/ tourists and procedures.

We cannot separate agri tourism and services as tangible products and intangible services. Agri tourism products include services too. Agri tourism products and services can be classified into following categories( Sznajder and Przezbórska, 2004; Mahliyanaarachchi, 2014).

a. According to the time of availability of product or service

- Products and services available at any time of the year

- Products and services available on particular time of the year

b. According to the requirement of the customers

- Tailor made products or services

- Readymade products or services

c. According to agri tourist activities

- Agri accommodation
- Direct marketing

- Farm tours

- Farm education programmes

- Farm festivals and cultural events

- Farm restaurant and food service

\section{Products and services available at any time of the year}

These are agri tourism products available throughout the year and easy to find due to their free availability. Agri tourism accommodations, farm restaurants, farm tours are available at any time of the year. The round the year availability of products or services also depends on the region or area. For instance, farm tours as banana tours, tea tours or cinnamon tours which are offered in tropical regions are available throughout the year. Farm tours as vine tours, berry farm tours, apple and pear tours are seasonal due to nature of agricultural production of these products.

Products and services available throughout the year are comparably cheaper than seasonal ones. Even in accommodation sector, there are peak times and off seasons according to the availability of tourists. During the peak time, in niche markets like agri accommodations, prices are higher than general hotel accommodation.

Farm restaurant is an agri tourism product that can be available throughout the year. However, in countries with temperate climate agri tourism products are marketable during the seasons with good weather conditions. In tropical and subtropical countries most of the agri tourism products are possible to offer to customers round the year.

\section{Products and services available on particular time of the year}

These are seasonal products. These products or services are available only in some seasons of the year or during specific time period. Some fruits such as mango, pears, apples, rabutan are available seasonally and harvesting of these 
fruits is also seasonal. Farm festivals are also available in a particular time. In south and south east Asia paddy planting and harvesting festivals are very popular and colorful in these countries. Most of these are cultural and related to religion (Buddhism, Hinduism) also. Visitors can watch these festivals and there rituals only during the available season, because these festivals cannot be demonstrated as mock festivals. While they are closely related with satisfying of gods, farmers are hesitated to make mock ones.

Due to seasonality and rareness of these seasonal products they are expensive. However in some cultures visitors can watch them in free of charge. These days even in rural area due to open economic situation, people try to make a value for everything. These are some challenges in agri tourism which is aiming to give positive impression on rural values to visitors.

\section{Tailor made products or services}

Agri tourism entrepreneurs can offer tailormade products or services to the visitors according to their wishes and requirements. As an example children from cities may not have seen cooking in clay pots with firewood. They may request to the farmer of the farm stay they want to experience cooking with firewood in clay pots. Therefore, farmer can organize requested type of cooking session in his farm. It is organized according to the requirement of the visitors and can be discussed in detail their requirement before planning it. Another example is visitors from a school may request to demonstrate milking manually. Farmer can organize day session of milking and allow them to learn hand milking. These are tailor made products and organize only in request of the visitors. Further farmer can charge for this type of services or products from the visitors. Tailor made products or services are expensive because farmer has to take extra effort and spend money to customize his services or products.

\section{Readymade products or services}

These products or services are already available in the farm or agri tourism enterprise and may be included into the tour package. As an example, in a banana tour in Ecuadorian banana plantation, all the activities from planting to processing and packaging of banana are included to the tour package. This shows that a tour package of banana tour includes transport facilities to and from the given point of gathering of visitors ( hotel, train station, bus station, airport, etc) to banana plantation, site seeing in the plantation, a tour guide service, involving in activities, Q \&A session, refreshments (or lunch or both) and any other action as per schedule. When a visitor buys banana tour package it includes all above with conditions or without conditions. Most of these tour packages are with conditions apply. A farm B \& B is included accommodation, breakfast, hospitality and farm tour into the package. These are readymade products and services and included into the tour package.

\section{Types of Agri tourism products}

Agri accommodation: Different types of farm accommodations are considered as agri tourism products. Farm accommodation is rated on the basis of standards accepted internationally and is a good business decision for owner/operators and their guests. According to the definition of a tourist, farm accommodation is the real agri tourism product. The definition of a tourist is "a person who is supposed to leave his/her hometown (permanent place) on temporary basis for the purpose of seeking new experiences, having fun $\&$ entertaining, doing sports, seeing cultural \& historical places (attractions) etc, on the condition that she/he should stay no less than one day (including a night) and no longer than 12 months, make use of a tourist facility for accommodation and spend her/his own money through their holiday" (Mahaliyanaarachchi, 2014). 
Direct marketing: Other Agri tourism product on the farm may include the direct marketing of farm products at the farm gate or a farmers' market. Innovative ideas using farm-based products have the greatest potential to earn the most money. Finding the niche markets and expanding on these unique opportunities can create the most rewarding and successful business ventures.

Different events on the farm, such as bee honey collection, U pickups, and farm restaurants with out-door BBQs can be instigated as direct marketing. Marketing niches such as water gardening supplies, herbal plants and products, flowers and exotic plants and breeding exotic animals can be added as farm based markets and require careful attention to constantly changing consumer trends. These can be very profitable if developed in conjunction with other agri tourism products (Mahaliyanaarachchi, 2014).

Farm tours: Farm tours can be organized in many different fashions. There may be just one farm hosting the tour, or a group of farms in a given area may be included, providing the tourists with an overall idea about agriculture in the area. Tours may be operated individually, where a family or group of people may choose to participate in the tour on their own. Farm Tours can be operated on a large scale, if tour operators include the farm tour into their tour package in advance. A packaged tour may include a half a day or one day tour of a farm and a processing plant so that the tourists will have a fuller understanding of the food chain from nursery stage, planting and up to harvesting, processing and marketing.

There are very good examples of this type of commercial farm tours in the world. Coffee Tours in Tanzania, Banana Tours in Central America, Wine tours in France, Whisky Tours in Scotland, Orange tours in Spain, Cinnamon Tours and Tea Tours in Sri Lanka are some of them. Also joining with tour operators, farmer groups can initiate various trails or driving routes, where a number of similar enterprises can be seen along the route such as a Tea Route, Cinnamon Route and Coconut Routes (Mahaliyanaarachchi, 2014).

\section{Use of agri tourism products in managing risk in farming}

There are only few studies conducted on farmers' perceptions of the economic benefits actually received from agri tourism and its mitigating ability of the effects of the risks faced by farmers. It has been observed that agri tourism, specifically farm-based accommodations is a "minor contributor" to the incomes of farmers in southern Germany (Oppermann, 1995; Busby and Rendle, 2000). However, past research confirms that agri tourism development in USA and rest of the world is often motivated by socially, including fulfillment of personal entrepreneurial goals, education of the public about farming, and social interactions with guests (George et al., 2011; McGehee, et al, 2007; Nickerson et al, 2001; Schilling, et al, 2012; Sharply and Vass, 2006; Weaver and Fennell, 1997). However, improving farm income is generally a primary motive behind the development of agri tourism enterprises. George et al., (2011) observe a range of net returns across different types of agri tourism attractions, concluding generally that agri tourism is a supplemental source of income for most farms.

However, Schilling et al., (2014) reveals that agri tourism farms in small farming category generate higher net cash returns per acre than their counterparts that do not engage in agri tourism. Similarly, operators of intermediate scale farms and smaller farms operated by individuals with stronger occupational ties to farming also appear to be finding success in agri tourism. Further they found that agri tourism has statistically significant and positive effects on farm profitability.

Agri tourism requires minimal additional investment and may utilize excess capacity 
of labor, capital, land, and natural resources. Excess capacity may allow farmers to increase the scope of activities. Promoting agri tourism in a farm or ranch is a revenue risk management strategy. Agri tourism attracts customers to farms or ranches. A pick your-own fruits or flowers enterprise or a nursery activity will attract families. These activities provide exercise, lots of fresh air, fresh food, fresh water, relaxation and something to take home (Mahaliyanaarachchi, 2015).

For farming communities trying to diversify their economies due to less profits and high risks, agri tourism offers compensating income source that allows a large financial range for capital expenditure, depending on how much the entrepreneur wants to invest. On the other hand young people in rural areas can start an agri tourism enterprise in their farm land which will be their main income source (Mahaliyanaarachchi, 2015; Brumfield and Mafoua 2002).

Further, agri tourism will motivate and encourage farming communities to raise their crops in eco friendly approach and to conserve the biodiversity of farms which will minimize the internal risk factors of farming such as pest and disease outbreaks, soil degradation, etc.

Research studies has shown that a well developed agri tourism industry would result in a market mechanism generating additional income of US \$251 to US \$364 million annually in counties like Dominican Republic (Catalino and Lizardo, 2004). Agri tourism sector would improve sustainable agricultural practices by maintaining and increasing positive externalities and nonmarket services provided by agriculture. Agri tourism products and services would have the added benefit of promoting sustainable agricultural practices too.

This is a good option for farmers and planters who are willing to diversify their farming operations that will help bringing more economic activities to rural areas sustaining livelihoods of the rural people. In addition agri tourism not only allows farmers to enjoy greater economic benefits through managing risks, but also helps to remain the young generation of the farming community in the rural areas instead of migrating to urban areas for better livelihoods.

Diversification of income sources is the only alternative to stay in agriculture for farmers with small and medium sized farms due to high risks they are facing such as production or yield risk, market or price risk, regulatory risk, financial risk and personal risk. One strategy to overcome these risks adopted by some innovative farmers is adding agri tourism as an alternative business in their farms. This is another way to adding value to the crops and livestock grown on the farm or ranch. It has a potential for building and expanding successful relationships between agriculture and tourism industries. Getting back to the agricultural and rural heritage roots and nature-based recreation experiences is a major tourist attraction trend today. Many of the natural resource conservation programmes in the agri tourism farms and rural landscapes are cherished by suburban and urban tourists both local and international.

Integrating agri tourism into current agricultural crop and livestock production is a way for a crop farm or a ranch to improve its income and grow livelihoods of the rural community. This helps farmers to mange different agricultural risks they faced. A specific feature of agri tourism is with relatively little initial investment, a working farm or ranch can be converted to an agri tourism enterprise.

\section{Positive aspects of agri tourism in managing risk in farming}

In term of positive aspects, agri tourism through green agriculture is a main expectation of agri tourism promotion. The farmers tend to reduce agricultural inputs from outside by means of organic farming or natural farming development as tourists attractions. Hence, environmental and natural resources available in the farm will 
serve as tourism resources instead of using for intensive agriculture (Ceballos, 1996). This will help to conserve available natural resources for effective management of agricultural risks faced by farmers. Farmers lose their income due to any kind of agricultural risk and it is important that any solution to manage these risks must compensate these income losses. Agri tourism is proven as a successful supplementary income source to the farmers (Schilling et al., 2014; Catalino and Lizardo, 2004).

\section{Negative aspects of agri tourism in managing risk in farming}

However, relationships between the farming and agri tourism activities may be competitive that may concern the use of agricultural resources of the farm, i.e. land, human resource, infrastructure and capital. For instance, a farmer growing commodity crops intend to develop agri tourism activity has to exclude part of the area of land from agricultural production and use it for agri tourism ( Sznajder, et al, 2009). Nevertheless, some experts suggest that even though agri tourism is associated closely with rural environment, but in the business environment, tourist farms also provide agricultural resources as accommodations and other facilities as other types of tourism business (Halfacree, 1993).

Further, in terms of tourism business model, it is a negative impact that most of agricultural resources are used for tourism and some cases the development of agri tourism activities is not an increasing factor of agricultural productivity (Brscic, 2006). Some researches reveal that the link between agri tourism and farming is getting weaker. In this view, farmers who engage in farm based tourism as an alternative source of income to mange risks in farming slowly dissociate themselves from agricultural activities (Busby and Rendle, 2000).

\section{CONCLUSIONS}

Risk management in agriculture is vital both for individual farmers and for agriculture as a sector because higher risks threaten sustainability of agriculture sector and it results in the collapse of both micro and macro economies in a country. Therefore, mitigation of effect of agricultural risks are important for progress of the sector and it is an essential need to identify appropriate risk management strategies to overcome these effects. Risk management should not concentrate on only one risk factor or only one solution. Diversification is a good strategy to reduce agricultural risk. Within the normal risk layer individual farmers are responsible and capable for managing their own business risk. Farmers adopt various strategies to manage risk affecting their production and income. Agri tourism is an enterprise that can be introduced to diversify farm business successfully.

It is observed that a range of net returns across different types of agri tourism attractions, concluding generally that agri tourism is a supplemental source of income for most farms. Therefore, we can conclude that agri tourism can be practiced as a successful risk management strategy in agriculture considering the global experiences.

\section{REFERENCES}

Brscic, K. (2006). The impact of agrotourism on agricultural production, Journal of Central European Agriculture Vol 7 (2006) No 3.

Brumfield, R. G., \& Mafoua, E. K. (2002). Agric tourism as income based risk management strategy for greenhouse and nursery producers [Electronic Version]. Rutgers cooperative Extension, New Jersey Agric Experiment station, New Jersey. Retrieved 13.062014 from http://www. linkbc.ca/torc/downs1/agritour.pdf?PHPSESSID=dfb8c15b25bcbfb9345baa5d0781d05f 
Busby, G., Rendle, S. (2000). The transition from tourism on farmers to farm tourism. Tourism Management 21 (6). Downloaded on 01.06.2011, http://www.sciencedirect.com.

Catalino A H, Lizardo M, (2004), Agriculture, Environmental Services andAgro-Tourism in the Dominican Republic, electronic Journal of Agricultural and Development Economics, Vol. 1, No. 1, pp. 87-116

Ceballos-Lascurain H(1996). Tourism, Ecotourism and Protected Areas. Gland, Switzerland IUCN - The World Conservation Union.

George, H., C. Getz, S. D. Hardesty, and E. Rilla (2011). "California Agritourism Operations and their Economic Potential Are Growing." California Agriculture 65(2011):57-65.

Halfacree, K. (1993). Locality and social representation: apace, discourse and alternative definitions of the rural, Journal of Rural Studies, 9 (1): 23-37

Hardaker, J.B., R. Huirne, J.R. Anderson and G. Lien (2004), Coping with risk in agriculture, $C A B$ I Publishing.

Huirne, R.B.M., M. Meuwissen, J.B. Hardacker and J.R. Anderson (2000), -Risk and risk management in agriculture: an overview and empirical resultsll, International Journal of Risk Assessment and Management, $\mathrm{N}^{\circ} 1:$ 125-136.

Jaffee S, Siegel P, and Andrews C (2010). Rapid Agricultural Supply Chain Risk Assessment: A Conceptual Framework, The World Bank. Washington. D.C.

Jorion, P. (2001), Value at Risk; The new Benchmark for managing Financial Risk, McGraw Hill Professional.

Mahaliyanaarachchi R P (2014), Agro Tourism, Department of Agri Business Management, Sabaragamuwa University of Sri Lanka

Mahaliyanaarachchi R P (2015) Role of Agri Tourism as a moderated rural business, Tourism, Leisure and Global Change, volume 2 , p.TOC- 193

McGehee, N. G., K. Kim, and G. R. Jennings (2007). Gender and Motivation for Agri-Tourism Entrepreneurship, Tourism Management 28:280-289.

Newbery, D.M. and J. Stiglitz (1981), The Theory of Commodity Prices Stabilization, Oxford University Press.

Nickerson, N. P., R. J. Black, and S. F. McCool (2001). Agritourism: Motivations behind Farm/ Ranch Business Diversification, Journal of Travel Research 40:19-26.

Oppermann, M (1995). "Holidays on the Farm: A Case Study of German Hosts and Guests", Journal of Travel Research 34:63-67

Orgnisation for Economic Corporation and Development (2008). An assessment of risk exposure in agriculture: A literature review. Part of the Trade and Agriculture Directorate project on Risk Management in Agriculture. 
Orgnisation for Economic Corporation and Development [OECD] (2009). Managing Risk in Agriculture, A Holistic Approach (extracts), download on 01.07.2015 http://www.oecd.org/ agriculture/agricultural-policies/45558582.pdf

Orgnisation for Economic Corporation and Development [OECD] (2009a). Risk Management in Agriculture: A Holistic Conceptual Framework. Part of the Trade and Agriculture Directorate project on Risk Management in Agriculture.

Orgnisation for Economic Corporation and Development [OECD] (2009b). The role of agriculture and farm household diversification in the rural economy of Germany, Trade and agriculture directorate

Schilling, B. J., K. P. Sullivan, and S. J. Komar (2012). "Examining the Economic Benefits of Agritourism: The Case of New Jersey." Journal of Agriculture, Food Systems, and Community Development 3:199-214.

Schilling B J, Attavanich W, Jin Y,(2014), Does Agritourism Enhance Farm Profitability? Journal of Agricultural and Resource Economics 39(1):69-87

Selvaraju R, (2014) Climate risk assessment and management in agriculture, FAO, download on 01.07.2015 http://www.fao.org/3/a-i3084e/i3084e06.pdf

Sharpley, R., and A. Vass(2006), Tourism, Farming and Diversification: An Attitudinal Study, Tourism Management 27:1040-1052.

Sznajder, M., Przezborska, L. and Scrimgeour, F. (2009). Agritourism. UK. Cabi Publishers

Sznajder M, Przezbórska L, (2004) Identification of Rural and Agri-Tourism Products and Services, Roczniki Akademii Rolniczej W Poznaniu - Ccclix, pp 165-177

Weaver, D. B., and D. A. Fennell. The Vacation Farm Sector in Saskatchewan: A Profile of Operations, Tourism Management 18(1997):357-365. 